\title{
The radio-protective effects of n-Hexane extracts of Telfairia occidentalis Hook. f. and Cucumeropsis mannii Naud. seed oils on the liver of irradiated male Wistar rats
}

\author{
Sarah Onyenibe NWOZO ${ }^{1,2}$, Michael O UKEJE${ }^{1} \&$ Josiah Eseoghene IFIE $^{2 *}$ \\ ${ }^{1}$ Nutrition and Industrial Biochemistry Unit, Department of Biochemistry, University of Ibadan, Ibadan, Oyo State, Nigeria \\ ${ }^{2}$ Department of Medical Biochemistry, Kampala International University, Western Campus, Bushenyi, Uganda \\ *Email: josiahifie@gmail.com
}

\section{ARTICLE HISTORY}

Received: 27 April 2020

Accepted: 22 May 2020

Published: 19 July 2020

KEYWORDS

Radiation

Telfairia occidentalis

Cucumeropsis mannii

Seed-oil extracts

Antioxidants

Liver

\section{ABSTRACT}

The human population is predisposed to some considerable amounts of radiation especially ionizing radiation which may negatively impact their metabolic processes. Herbal extracts can mitigate these harmful effects. Therefore, this study aims to investigate the protective effect of $n$-Hexane extracts of Telfairia occidentalis and Cucumeropsis mannii seeds oils against radiation-mediated oxidative stress in Wistar rats. Sixty male rats were randomly distributed into six groups of six animals each and $n$-hexane extracts of T. occidentalis and C. mannii were administered at a dose of 2.4 or $4.8 \mathrm{mg} / \mathrm{kg} \mathrm{b}$. wt., orally for 7 days before irradiation and 10 days after irradiation, when they were sacrificed. Lipid peroxidation was measured, hepatic antioxidant status; SOD, CAT, GSH, Gpx and GST were estimated. The activities of liver enzymes: ALT, AST and ALP were measured and histological examination of sections of the liver was carried out. Radiation significantly increased MDA levels, SOD, GPx, AST, ALT and ALP activities but reduced body weights, total proteins, CAT, GSH and GST activities. Administration of the extracts significantly reduces the levels of MDA, SOD, GPx, ALT, AST and ALP activities while they increase the activities of CAT, GSH and GST at a dosage of $4.8 \mathrm{mg} / \mathrm{kg}$. Histological examination showed increased levels of toxicity in radiated and groups administered $2.4 \mathrm{mg} / \mathrm{kg}$ extracts. From these findings, extracts of T. occidentalis and C. mannii at $4.8 \mathrm{mg} / \mathrm{kg} \mathrm{b}$. wt are effective herbal remedies in the prevention and amelioration of the consequences of oxidative stress due to exposure to ionizing radiation.

\section{Introduction}

The human population is predisposed to some considerable amounts of radiation especially ionizing radiation (1). Even if considerable research studies on their dangerous consequences have been documented, humans cannot be fully exempted from absorbing rays intentionally or unintentionally in our daily activities (1). Among the ionizing radiations encountered by humans, one of the most harmful is the radiation from gamma rays which have large energy and a short wavelength (2). Gamma rays can break the barriers of living organisms during their transmission, transmit their radiant energy to biological molecules within the cells and induce oxidative stress by the production of reacting oxygen species (ROS) and free radicals (2-4).
Free radicals have been implicated in the incidence, occurrence and distribution of most metabolic abnormalities such as compromised cell membranes integrity, spleen dysfunction, cancer of the lungs and various other malignancies (1-3). The cytotoxic effects induced by ionizing radiation in normal tissues are reduced or ameliorated through the administration of various organic compounds with therapeutic potential as well as the capability of scavenging the free radicals $(4,5)$. These compounds are known as radioprotective agents and could be of synthetic or of plant origin (6). Those of plant origin are preferred because they pose little or no side effects (7) and Vegetables such as Telfairia occidentalis Hook. f. and Cucumeropsis mannii Naud. are good examples $(6,7)$.

(c) Nwozo et al (2020). This is an open-access article distributed under the terms of the Creative Commons Attribution License, which permits unrestricted use, distribution and reproduction in any medium, provided the original author and source are credited (https://creativecommons.org/licenses/by/4.0/)

To cite this article: Nwozo S O, Ukeje M O, Ifie J E. The radio-protective effects of n-Hexane extracts of Telfairia occidentalis Hook. f. and Cucumeropsis mannii Naud. seed oils on the liver of irradiated male Wistar rats. Plant Science Today. 2020;7(3):432-440. https://doi.org/10.14719/pst.2020.7.3.805 
T. occidentalis otherwise called 'fluted pumpkin' belonging to the family of Cucurbitaceae, is one of the most common tropical vines cultivated in Sub-Sahara Africa especially the Western region. This vegetable commonly called the 'Ugu' in the most southern parts of Nigeria, is cultivated for its leaves and seeds which are processed as additives to foods (8). Cucumeropsis mannii which also belongs to the family of Cucurbitaceae is widely distributed around the tropics and they possess fibrous and shallow roots (9). They are usually called 'melon or egusi' and are processed for their edible seeds which contain various minerals including sodium and potassium as well as vitamins such as retinol and tocopherols (10, 11).

Most studies on plant biodiversities concerning their medicinal and therapeutic potentials have a focus on the plants' leaves, stems and barks and studies on $T$. occidentalis and $C$. mannii are not exceptions. Some studies of the leaves of $T$. occidentalis include its ability to ameliorate damages caused by oxidative stress as a result of a high dosage of alcohol is by controlling the production of biomarkers for oxidative stress (8).

The effect of the aqueous extract of the leaf of $T$. occidentalis on performances and indices of hematology of starter broilers have been studied (12). Also, its effects on hematological parameters such as packed cell volumes, blood cells and hemoglobin on Wistar rats were studied by and these studies postulated that $T$. occidentalis can be used as an effective blood-booster for the management of anemia (13). The methanolic extracts of $T$. occidentalis have been shown to possess antioxidant activities, hypolipidemic, antidiabetic and hepatoprotective potentials when investigated using rats models (14-16). The effect of the phenolic extracts of $C$. mannii seeds has been studied and shown to have inhibitory potentials against arginase and phosphodiesterase enzymes which are key enzymes in the occurrence of erectile dysfunction, thus can be used as an erectogenic herb in the management of erectile dysfunction (17).

Notwithstanding the investigations on the potentials of $T$. occidentalis and $C$. mannii more researches are still needed to fully uncover their medicinal relevances. The investigation of the radioprotective effects of n-Hexane extracts of $T$. occidentalis and $C$. mannii seed oils on the liver of irradiated male Wistar rats is aimed at using the extracts of $T$. occidentalis and $C$. mannii seed oils as a herbal remedy in the prevention and amelioration of the oxidative consequences of exposure to radiation.

\section{Materials and Methods}

\section{Plant materials and extraction procedure}

Fresh seeds of $T$. occidentalis (T.O) and $C$. mannii (C.M) were obtained from the Bodija market, Ibadan, Oyo State, Nigeria. These seeds were identified, authenticated and samples were kept with the Herbarium of Department of Botany, University of Ibadan, Nigeria. The extraction of the seed oils were by the method described (18). The seeds were aired dried at room temperature in the Laboratory about washing. The dried seeds were kept in clean dried bottles and later blended manually to obtain a powdered form. $30 \mathrm{~g}$ of the powdered seeds were extracted with $250 \mathrm{ml}$ n-hexane using a Soxhlet extractor at $70{ }^{\circ} \mathrm{C}$ for $6 \mathrm{hr}$. After extraction, the solvent was removed from the oil using a rotary evaporator to obtain the crude oil extract. The crude oil was clarified by using $0.1 \mathrm{M} \mathrm{NaOH}$ at $65^{\circ} \mathrm{C}$ and bleached by using bentonite clay at $105^{\circ} \mathrm{C}$ for $1 \mathrm{hr}$. Desolventization of the extraction solvent was by flashing between $80-100^{\circ} \mathrm{C}$.

\section{Experimental design}

Sixty adult male Wistar rats (125-150 g) were used for this study. For acclimatization, the rats were housed in a ventilated rat cage for two weeks. They were fed with normal laboratory feeds and water ad libitum. The rats were divided into six groups randomly with 6 rats per group. Rats in group I were negative control and received only pellets feed while group II was positive control (IR) which was irradiated with 6 Gy and fed with pellets feeds. Group III pairs received $2.4 \mathrm{mg} / \mathrm{kg}$ b.wt T.O. and C.M. respectively while group IV pairs received $4.8 \mathrm{mg} / \mathrm{kg}$ b.wt without radiation. Group V pairs received 2.4 $\mathrm{mg} / \mathrm{kg}$ b.wt T.O. and C.M. (2.4 mg/kg b.wt T.O + IR and $2.4 \mathrm{mg} / \mathrm{kg}$ b.wt C.M. +IR) respectively while group IV pairs received $4.8 \mathrm{mg} / \mathrm{kg}$ b.wt $(4.8 \mathrm{mg} / \mathrm{kg}$ b.wt T.O + IR and $4.8 \mathrm{mg} / \mathrm{kg}$ b.wt C.M. +IR) respectively with radiation.

The crude oil extracts were administered orally at a dosage of $2.4 \mathrm{mg} / \mathrm{kg} \mathrm{b.wt}$ and $4.8 \mathrm{mg} / \mathrm{kg} \mathrm{b} . w \mathrm{t}$ for 7 days, before and 10 days after irradiation. The irradiation was according to the described method of (1). "The animals were exposed to a single dose of 600 rads ( $6 \mathrm{~Gy}$ ) of whole-body gamma radiation from a 60 Co source gamma chamber (Model 220, Atomic Energy of Canada Ltd.) used in the Radiotherapy Unit of the University College Hospital (Ibadan, Nigeria)".

\section{Tissue Preparation for Sample Collection and Histological studies}

10 days after irradiation and administration of extracts, blood samples were collected in a plain tube by ocular puncture technique for clotting. Serum was obtained by centrifugation of the clotted blood samples at $4000 \mathrm{~g}$ for $15 \mathrm{mins}$ and stored for biochemical analysis (1). The rats in each of the groups were sacrificed and their livers were harvested for liver homogenate preparation. The harvested livers were rinsed in $1.15 \% \mathrm{KCl}$ buffer, weighed and placed in a Teflon homogenizer of buffer pH 7.4. The liver homogenates were centrifuged $\left(4^{\circ} \mathrm{C}\right)$ and the collected supernatant was stored for biochemical analysis (1).

\section{Biochemical Analysis}

The concentration of total proteins was by the Biuret method using bovine serum albumin as a standard (19). Lipid peroxidation (LPO) was quantified by the thiobarbituric acid (TBA) method in which the concentration of MDA; Malondialdehyde formed per mg protein was estimated (20). Activity of Catalase (CAT) was measured by the rate of decomposition of 
hydrogen peroxide at $570 \mathrm{~nm}$ (21) while superoxide dismutase (SOD) activity was assayed according to described methods respectively $(21,22)$. Activities of Glutathione enzymes; Glutathione Peroxidase (GPx) and glutathione S-transferase (GST) were determined according to described methods $(23,24)$. Nonenzymatic glutathione (GSH) concentration was estimated by the described method (25).

Randox commercial Enzyme kits were used to assay for the Liver function biomarkers: Alanine Amino-Transferase (ALT), Aspartate AminoTransferase (AST) and Alkaline phosphatase (ALP) according to described methods (26). A small portion of the liver was fixed in $10 \%$ neutral buffered formalin for histological examination which was carried out at the Department of Veterinary Anatomy, University of Ibadan, Ibadan. This was carried out according to the described methods (1, 16).

\section{Statistical analysis}

Data collected from this study were analyzed using the two-way analysis of variance for the effect of radiation and treatment extracts. This was followed by a post-hoc LSD test using the SPSS statistical analysis software (SPSS-20®). All statistical analysis was performed at a confidence limit of $95 \%(p=0.05)$ and values are presented as mean \pm standard deviation.

\section{Results}

The results obtained from the investigation of the effects of the extracts of $T$. occidentalis and $C$. mannii in the prevention of the consequences of radiation on the male Wistar rats are given in the tables and figures described below.

Table 1 shows the effects of n-Hexane Extract of $T$. occidentalis and $C$. mannii on body weight (g) after exposure to radiation. Irradiation significantly reduced the body weight of group II by $15.91 \%$ compared to other groups. The bodyweights of groups administered the extracts of T.O. and C.M. at $2.4 \mathrm{mg} / \mathrm{kg}$ and $4.8 \mathrm{mg} / \mathrm{kg}$ were insignificantly increase radiation showed reduced the total proteins $(p<0.05)$ when compared with group I. The total proteins of the groups administered the extracts of $T$. occidentalis and $C$. mannii at $2.4 \mathrm{mg} / \mathrm{kg}$ and $4.8 \mathrm{mg} / \mathrm{kg}$ showed increased $(p<0.05)$ mean values when compared with group II (IR) in a concentrationdependent manner.

Table 3 shows the effects of n-hexane extracts of T. occidentalis and $C$. manni on hepatic LPO Levels, SOD and CAT (U/mg proteins) activities after exposure to radiation (6 Gy). MDA levels and SOD activity were increased in group II exposed to radiation but CAT activities were reduced. Administration of the extracts of T. occidentalis at 4.8 $\mathrm{mg} / \mathrm{kg}$ significantly reduced MDA levels and SOD activities while CAT activities were increased. Administration of the extracts of T. occidentalis at 2.4 $\mathrm{mg} / \mathrm{kg}$ insignificant mean values when compared to group exposed to radiation only. Extracts of $C$. mannii significantly decreased values for MDA and SOD at $4.8 \mathrm{mg} / \mathrm{kg}$ but was unchanged at $2.8 \mathrm{mg} / \mathrm{kg}$. However, the activities of CAT were significantly increased when $2.4 \mathrm{mg} / \mathrm{kg}$ and $4.8 \mathrm{mg} / \mathrm{kg}$ extracts of $C$. mannii were administered. The effects of n-Hexane Extracts of $T$. occidentalis and $C$. mannii on Hepatic Intracellular Glutathione Enzymes activities after exposure to radiation (6 Gy) were shown in Table 4. Administration of $2.4 \mathrm{mg} / \mathrm{kg}$ and $4.8 \mathrm{mg} / \mathrm{kg}$ of the extracts of $T$. occidentalis and $C$. mannii significantly decreased GSH and GPx activities while GST activities remained unchanged in groups not exposed to radiation. In groups exposed to radiation, the values of GSH and GPx were unchanged while GST is significantly reduced when extracts were administered at $2.4 \mathrm{mg} / \mathrm{kg}$. Extracts at $4.8 \mathrm{mg} / \mathrm{kg}$ significantly increased the concentration of GSH and GST activities while GPx is unchanged.

The effects of n-hexane extracts of $T$. occidentalis and $C$. mannii on serum AST levels (U/L) of rats After exposure to radiation (6 Gy) were shown in Fig. 1. The mean values of AST were higher in groups exposed to radiation only when compared to the control group $(p<0.05)$. AST levels were significantly reduced in groups administered $4.8 \mathrm{mg} / \mathrm{kg}$ extracts of $T$. occidentalis and $C$. mannii but remained

Table 1. Effects of n-Hexane extract of $T$. occidentalis and $C$. mannii on body weight (g) after exposure to radiation

\begin{tabular}{|c|c|c|c|c|c|c|}
\hline \multirow{2}{*}{ Treated Groups } & \multicolumn{3}{|c|}{ T. occidentalis } & \multicolumn{3}{|c|}{ C. mannii } \\
\hline & Initial b.wt (g) & Final b.wt (g) & $\%$ increase/loss & Initial b.wt (g) & Final b.wt (g) & \%increase/loss \\
\hline Group I (Control) & $141.96 \pm 13.92$ & $156.81 \pm 19.76$ & $10.46^{\mathrm{b}}$ & $141.96 \pm 13.92$ & $156.81 \pm 19.76$ & $10.46^{\mathrm{b}}$ \\
\hline Group II (IR) & $152.34 \pm 18.99$ & $128.10 \pm 23.07$ & $-15.91^{a}$ & $152.34 \pm 18.99$ & $128.10 \pm 23.07^{a}$ & $-15.91^{\mathrm{a}}$ \\
\hline Group III $(2.4$ ml/kg) & $135.43 \pm 6.680$ & $146.18 \pm 11.97$ & $7.94^{\mathrm{b}}$ & $134.64 \pm 12.11$ & $143.44 \pm 10.06^{\mathrm{a}}$ & $6.54^{\mathrm{b}}$ \\
\hline Group IV (4.8 ml/kg) & $134.91 \pm 10.90$ & $132.29 \pm 10.20$ & $-1.94^{\mathrm{d}}$ & $133.01 \pm 9.261$ & $127.34 \pm 9.85^{\mathrm{a}}$ & $-4.26^{c}$ \\
\hline Group V (IR+2.4 ml/kg) & $134.60 \pm 10.31$ & $126.02 \pm 9.300^{\mathrm{a}}$ & $-6.37^{c}$ & $140.38 \pm 15.42$ & $130.74 \pm 16.26$ & $-6.87^{c}$ \\
\hline Group VI (IR+4.8 ml/kg) & $137.74 \pm 13.89$ & $139.62 \pm 10.00^{\mathrm{a}}$ & $1.36^{\mathrm{d}}$ & $133.46 \pm 0.50 \mathrm{a}$ & $136.51 \pm 2.42$ & $2.29^{\mathrm{d}}$ \\
\hline
\end{tabular}

Values are expressed as mean \pm S.D. for $n=6$

* Mean values with different letters represent statistical significance $(p<0.05)$

body weight when compared to groups I and II. The effects of the seed oil extracts of T.O and C.M. on the serum total proteins after exposure to radiation were shown in Table 2. Group II which were exposed to unchanged at $2.4 \mathrm{mg} / \mathrm{kg}$ when compared to the groups exposed to radiation only. Fig. 2 shows the effects of n-hexane extracts of $T$. occidentalis and $C$. mannii on serum ALT levels (U/L) of rats After 
Table 2. Effects of n-Hexane extracts of T. occidentalis and C. mannii on Serum Total Proteins (mg/g) after exposure to radiation

\begin{tabular}{lrr}
\hline & & \multicolumn{1}{c}{ Serum Total Proteins (mg/g) } \\
\cline { 2 - 3 } Treated Groups & T. occidentalis & C. mannii \\
\cline { 2 - 3 } Group I (Control) & $92.81 \pm 11.43^{\mathrm{a}}$ & $92.81 \pm 11.43^{\mathrm{a}}$ \\
Group II (IR) & $63.53 \pm 2.73^{\mathrm{c}}$ & $63.53 \pm 2.73^{\mathrm{c}}$ \\
Group III ( $.4 \mathrm{ml} / \mathrm{kg})$ & $94.31 \pm 3.02^{\mathrm{a}}$ & $95.23 \pm 8.93^{\mathrm{a}}$ \\
Group IV (4.8 ml/kg) & $91.86 \pm 2.08^{\mathrm{a}}$ & $99.31 \pm 6.11^{\mathrm{a}}$ \\
Group V (IR+2.4 ml/kg) & $77.65 \pm 5.02^{\mathrm{b}}$ & $76.18 \pm 1.08^{\mathrm{b}}$ \\
Group VI (IR+4.8 ml/kg) & $85.49 \pm 3.27^{\mathrm{a}}$ & $88.17 \pm 0.40^{\mathrm{a}}$ \\
\hline Values are expressed as mean + S.D. for $n=6$ & &
\end{tabular}

Values are expressed as mean \pm S.D. for $n=6$

*Mean values with different letters represent statistical significance $(p<0.05)$

Table 3. Effects of n-hexane extracts of T. occidentalis and C. manni on hepatic LPO Levels, SOD and CAT (U/mg proteins) activities after exposure to radiation (6 Gy)

\begin{tabular}{lccccccc}
\hline \multirow{2}{*}{ Treated Groups } & \multicolumn{2}{c}{$\begin{array}{c}\text { LPO } \\
\text { (nU MDA/mg/Protein) }\end{array}$} & \multicolumn{2}{c}{$\begin{array}{c}\text { SOD } \\
\text { (U/mg proteins) }\end{array}$} & \multicolumn{2}{c}{$\begin{array}{c}\text { CAT } \\
\text { (U/mg proteins) }\end{array}$} \\
\cline { 2 - 8 } & T. occidentalis & C. mannii & T. occidentalis & C. mannii & T. occidentalis & C. mannii \\
\hline Group I (Control) & $10.21 \pm 2.28^{\mathrm{b}, \mathrm{c}}$ & $10.2 \pm 2.28^{\mathrm{b}, \mathrm{c}}$ & $5.87 \pm 0.68^{\mathrm{b}, \mathrm{c}}$ & $5.87 \pm 0.68^{\mathrm{b}, \mathrm{c}}$ & $59.55 \pm 2.05^{\mathrm{b}}$ & $59.55 \pm 2.05^{\mathrm{b}}$ \\
Group II (IR) & $18.61 \pm 1.46^{\mathrm{a}}$ & $18.61 \pm 1.46^{\mathrm{a}}$ & $7.41 \pm 0.29^{\mathrm{a}}$ & $7.41 \pm 0.28^{\mathrm{a}}$ & $48.39 \pm 4.42^{\mathrm{c}}$ & $48.39 \pm 4.42^{\mathrm{c}}$ \\
Group III (2.4 ml/kg) & $9.88 \pm 1.34^{\mathrm{c}}$ & $10.13 \pm 0.91^{\mathrm{b}, \mathrm{c}}$ & $7.38 \pm 0.40^{\mathrm{a}}$ & $4.82 \pm 0.22^{\mathrm{c}}$ & $75.17 \pm 9.97^{\mathrm{a}}$ & $46.32 \pm 1.52^{\mathrm{c}}$ \\
Group IV (4.8 ml/kg) & $10.82 \pm 5.33^{\mathrm{b}, \mathrm{c}}$ & $9.97 \pm 1.01^{\mathrm{c}}$ & $5.57 \pm 0.16^{\mathrm{b}, \mathrm{c}}$ & $5.46 \pm 0.10^{\mathrm{b}}$ & $85.53 \pm 4.17^{\mathrm{a}}$ & $48.59 \pm 2.88^{\mathrm{c}}$ \\
Group V (IR+2.4 ml/kg) & $18.13 \pm 2.09^{\mathrm{a}}$ & $19.51 \pm 2.34^{\mathrm{a}}$ & $8.78 \pm 1.56^{\mathrm{a}}$ & $6.48 \pm 1.14^{\mathrm{b}}$ & $50.38 \pm 2.84^{\mathrm{b}, \mathrm{c}}$ & $61.11 \pm 10.34^{\mathrm{b}}$ \\
Group VI (IR+4.8 ml/kg) & $14.52 \pm 2.68^{\mathrm{b}}$ & $14.71 \pm 2.11^{\mathrm{b}}$ & $6.37 \pm 0.45^{\mathrm{b}}$ & $6.88 \pm 0.05^{\mathrm{b}}$ & $55.86 \pm 3.44^{\mathrm{b}, \mathrm{c}}$ & $64.93 \pm 1.27^{\mathrm{b}}$ \\
\hline
\end{tabular}

Values are expressed as mean \pm S.D. for $n=6$

*Mean values with different letters represent statistical significance $(p<0.05)$

Table 4. Effect of n-Hexane extracts of T. occidentalis and C. mannii on hepatic intracellular glutathione enzymes activities after exposure to radiation (6 Gy)

\begin{tabular}{|c|c|c|c|c|c|c|}
\hline \multirow{2}{*}{ Treatment groups } & \multicolumn{2}{|c|}{ GSH ( $\mu \mathrm{mol} / \mathrm{mg}$ Protein) } & \multicolumn{2}{|c|}{ Gpx ( $\mu \mathrm{molGSH} / \mathrm{mg}$ protein) } & \multicolumn{2}{|c|}{ GST ( $\mu \mathrm{mol} / \mathrm{mins} / \mathrm{mg}$ protein) } \\
\hline & T. occidentalis & C. mannii & T. occidentalis & C. mannii & T. occidentalis & C. mannii \\
\hline Group I (Control) & $24.25 \pm 4.193^{\mathrm{a}, \mathrm{b}}$ & $24.25 \pm 4.193^{\mathrm{a}, \mathrm{b}}$ & $2.70 \pm 0.39^{c}$ & $2.70 \pm 0.39^{c}$ & $1.32 \pm 0.27^{\mathrm{a}}$ & $1.32 \pm 0.27^{\mathrm{a}}$ \\
\hline Group II (IR) & $11.75 \pm 1.291^{\mathrm{c}}$ & $11.75 \pm 1.291^{\mathrm{c}}$ & $3.67 \pm 0.27^{\mathrm{b}, \mathrm{c}}$ & $3.67 \pm 0.27^{\mathrm{b}, \mathrm{c}}$ & $0.84 \pm 0.81^{b}$ & $0.84 \pm 0.81^{\mathrm{b}}$ \\
\hline Group III (2.4 ml/kg) & $29.69 \pm 3.430^{\mathrm{a}}$ & $26.50 \pm 1.756^{\mathrm{a}}$ & $4.81 \pm 0.76^{\mathrm{a}, \mathrm{b}}$ & $3.09 \pm 0.35^{\mathrm{b}, \mathrm{c}}$ & $1.31 \pm 0.16^{\mathrm{a}}$ & $1.25 \pm 0.43^{\mathrm{a}}$ \\
\hline Group IV (4.8 ml/kg) & $29.63 \pm 1.451^{\mathrm{a}}$ & $30.33 \pm 2.376^{\mathrm{a}}$ & $4.33 \pm 1.04^{\mathrm{a}, \mathrm{b}}$ & $2.86 \pm 0.22^{c}$ & $1.09 \pm 0.04^{\mathrm{a}, \mathrm{b}}$ & $0.73 \pm 0.029^{b}$ \\
\hline Group V (IR+2.4 ml/kg) & $12.38 \pm 0.595^{\mathrm{c}}$ & $12.33 \pm 0.38^{\mathrm{c}}$ & $5.30 \pm 0.54^{\mathrm{a}}$ & $3.10 \pm 0.01^{b, c}$ & $1.30 \pm 0.38^{\mathrm{a}}$ & $1.31 \pm 0.38^{\mathrm{a}}$ \\
\hline Group VI (IR+4.8 ml/kg) & $18.42 \pm 0.577^{b}$ & $19.17 \pm 0.38^{\mathrm{b}}$ & $3.59 \pm 0.28^{\mathrm{b}, \mathrm{c}}$ & $3.78 \pm 0.01^{\mathrm{b}, \mathrm{c}}$ & $1.33 \pm 0.29^{\mathrm{a}}$ & $1.03 \pm 0.11^{\mathrm{a}, \mathrm{b}}$ \\
\hline
\end{tabular}

Values are expressed as mean \pm S.D. for $n=6$

${ }^{*}$ Mean values with different letters represent statistical significance $(p<0.05)$

exposure to radiation (6 Gy). The mean values of Group II (IR) were higher than group I $(p<0.05)$. Comparison of $T$. occidentalis and $C$. mannii showed that only $4.8 \mathrm{mg} / \mathrm{kg}$ extracts of $T$. occidentalis can significantly reduce ALT after radiation. The mean values of serum ALT were higher in groups exposed to radiation only (Fig. 2). These values were significantly reduced when extracts of $T$. occidentalis and C. mannii were administered at $4.8 \mathrm{mg} / \mathrm{kg}$ but remained unchanged at $2.4 \mathrm{mg} / \mathrm{kg}$. For ALP as shown in Fig. 3, the values were higher in group exposed to radiation $(p<0.05) .4 .8 \mathrm{mg} / \mathrm{kg}$ extracts of both $T$. occidentalis and $C$. mannii significantly reduced ALP $(p<0.05$ while extracts administered at $2.4 \mathrm{mg} / \mathrm{kg}$ showed insignificant values ( $p>0.05)$.

The histological analysis of liver sections on the effect of $T$. occidentalis after exposure to radiation was shown in Fig. 4. Slide B which belongs to groups exposed to radiation only showed the presence of severe portal congestion and vacuolar degeneration associated with a stressed liver. Slide A which belongs to the control group, showed no visible lesion. Also, slides C and D which belong to groups administered only extracts of $T$. occidentalis showed no visible lesion. Slide F showed slight to moderate vacuolar degeneration while slide $\mathrm{E}$ which is group irradiated and administered $2.4 \mathrm{mg} / \mathrm{kg}$ of extracts, still maintained severe vacuolar degeneration similar to slide $B$. The observations of the histological analysis of liver sections on the effects of $C$. mannii after exposure to radiation shown in slides A-F (Fig. 5) were similar to those of the administration of extracts of $T$. occidentalis.

\section{Discussion}

Living organisms are exposed to some amounts of radiation especially ionizing radiations during radiotherapy and transmit their radiant energy to 


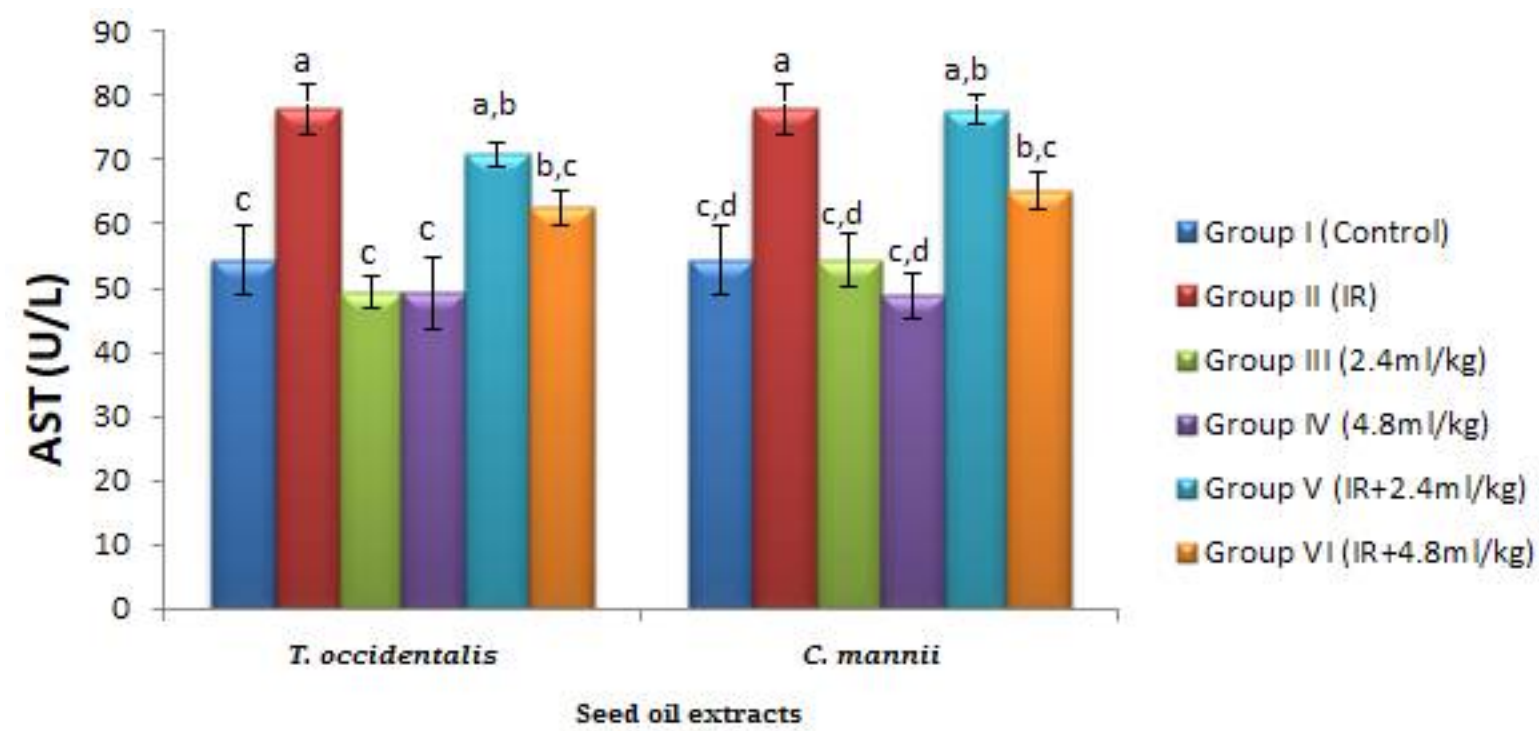

Fig. 1. Effects of n-hexane extracts of T. occidentalis and C. mannii on serum AST levels (U/L) of rats after exposure to radiation (6 Gy). ${ }^{*}$ Mean values with different letters represent statistical significance $(p<0.05)$

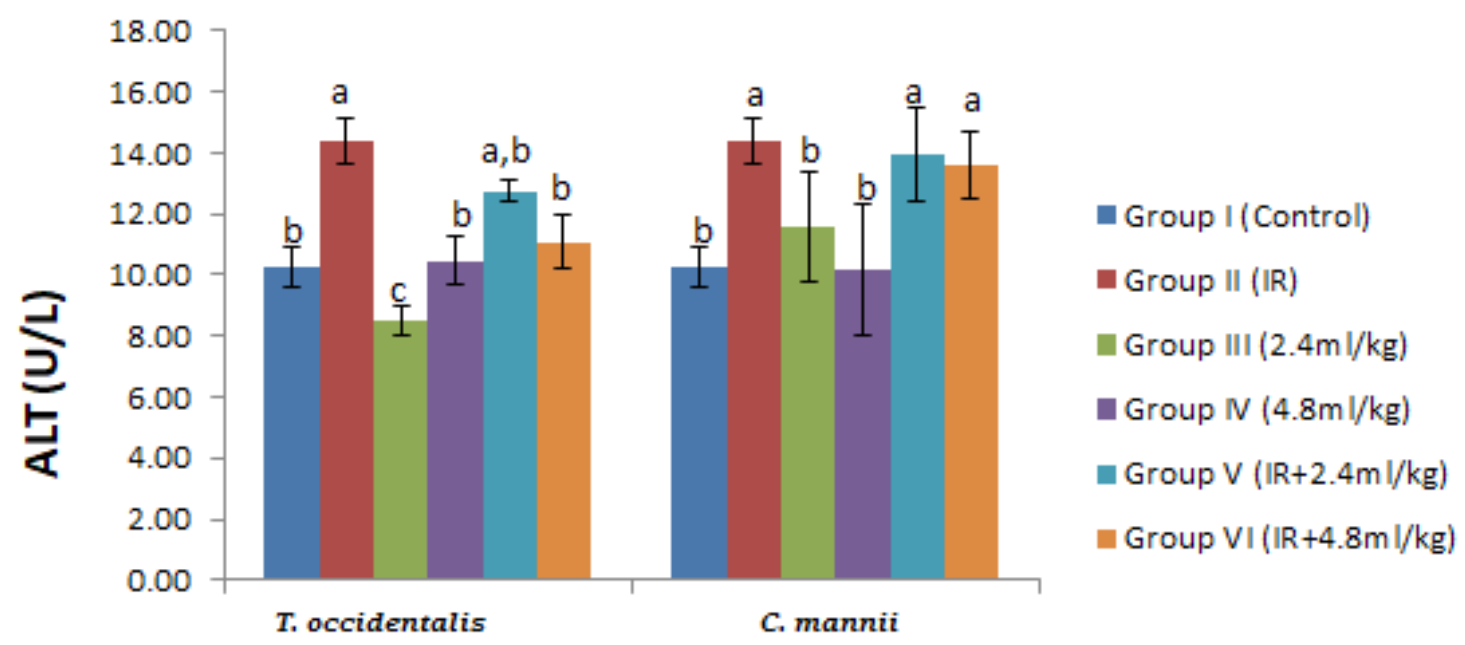

Seed oil extracts

Fig. 2. Effects of n-hexane extracts of $T$. occidentalis and $C$. mannii on serum ALT levels (U/L) of rats after exposure to radiation.(6 Gy). ${ }^{*}$ Mean values with different letters represent statistical significance $(p<0.05)$

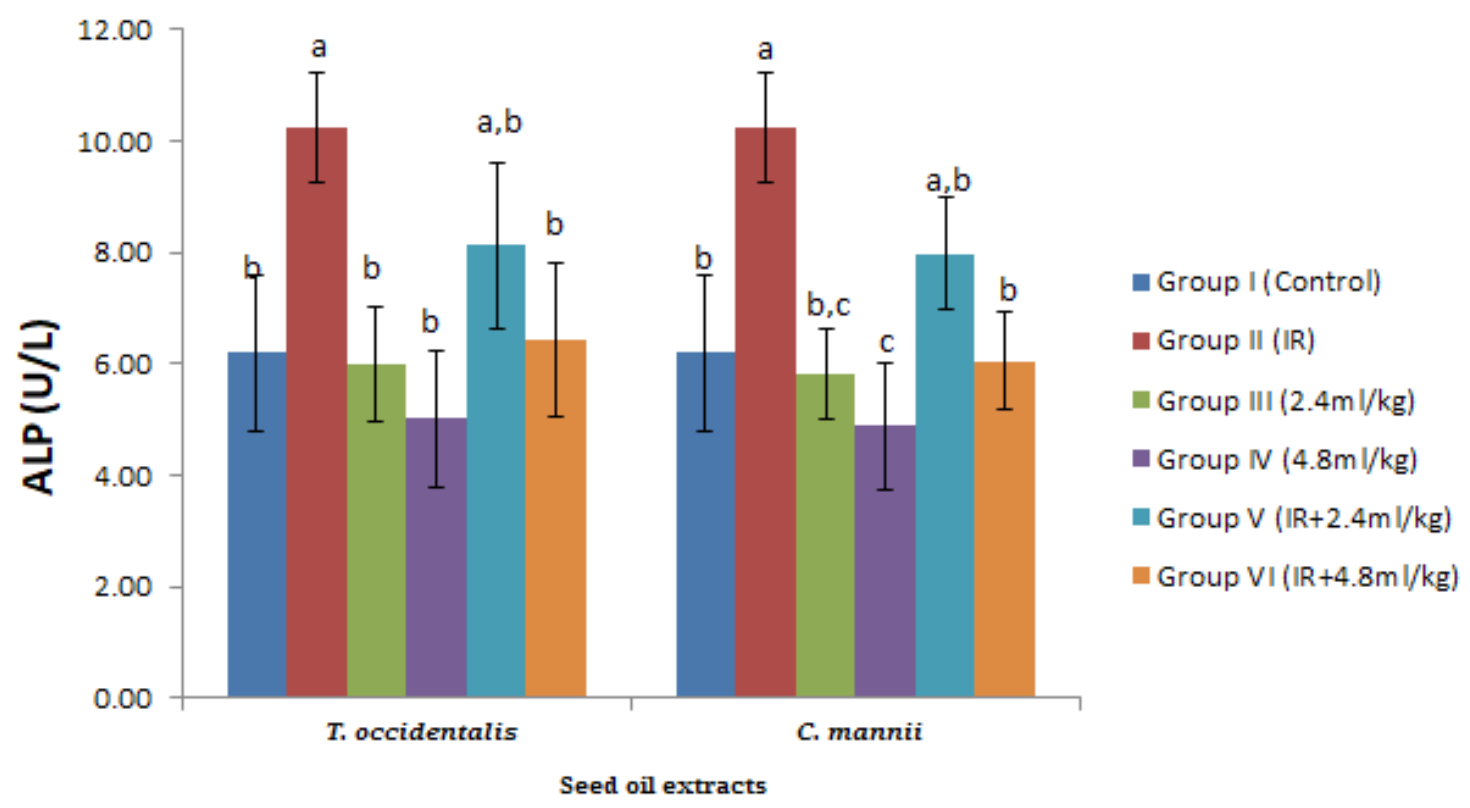

Fig. 3. Effects of n-hexane extracts of $T$. occidentalis and $C$. mannii on serum ALP levels (U/L) of rats after exposure to radiation (6 Gy). ${ }^{*}$ Mean values with different letters represent statistical significance $(p<0.05)$ 

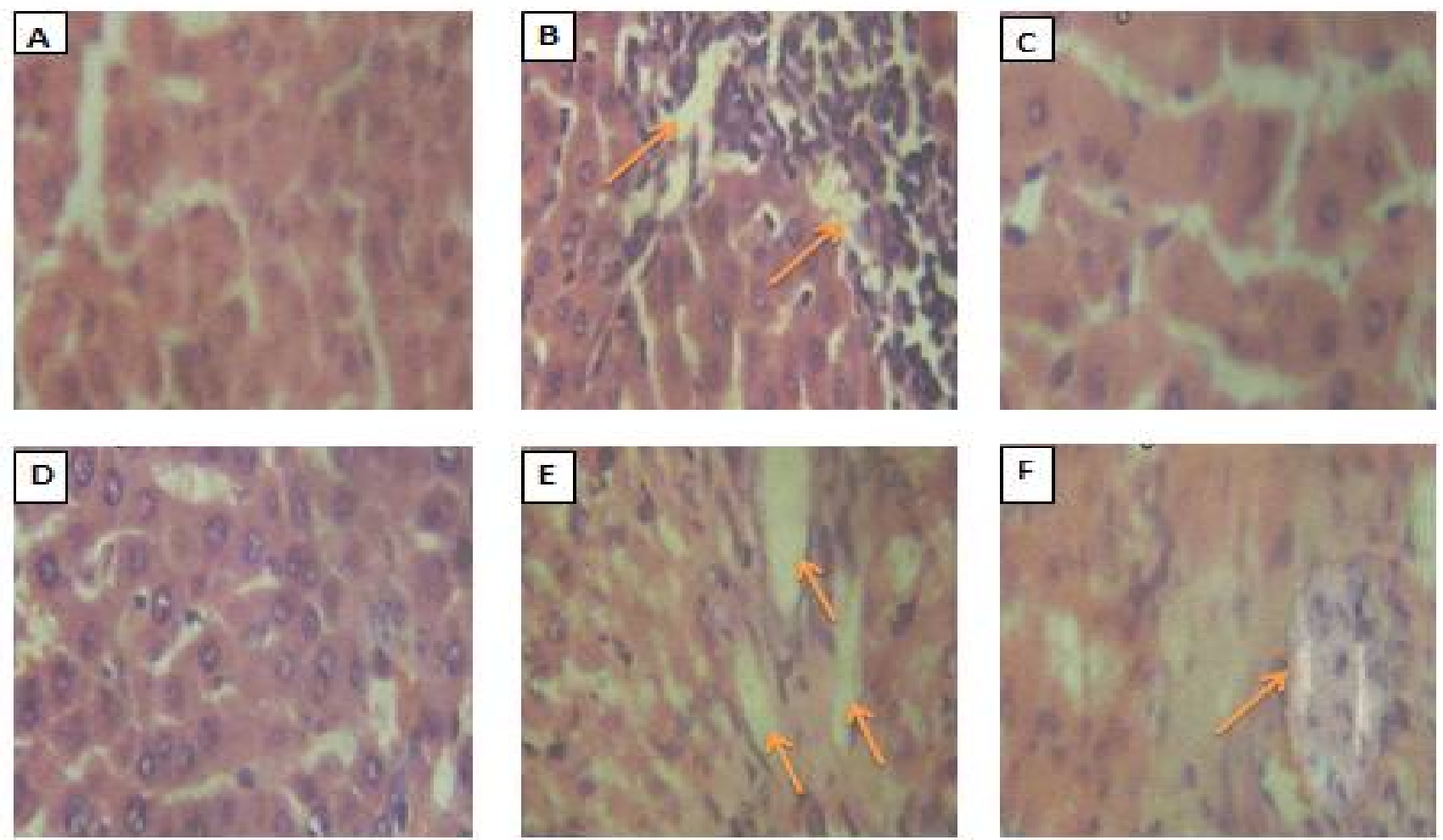

Fig. 4. Histological analysis of liver sections on the effect of $T$. occidentalis after expose to radiation.

*Hepatocytes showing abnormal morphology are represented by the yellow arrow. A: Group I (control), B: Group II (IR only), C: Group III (2.4 mg/kg b. wt.), D: Group IV (4.8 mg/kg b. wt.), E: Group V (IR + $2.4 \mathrm{mg} / \mathrm{kg}$ b. wt.) and F: Group VI (IR + $4.8 \mathrm{mg} / \mathrm{kg} \mathrm{b.} \mathrm{wt.)}$
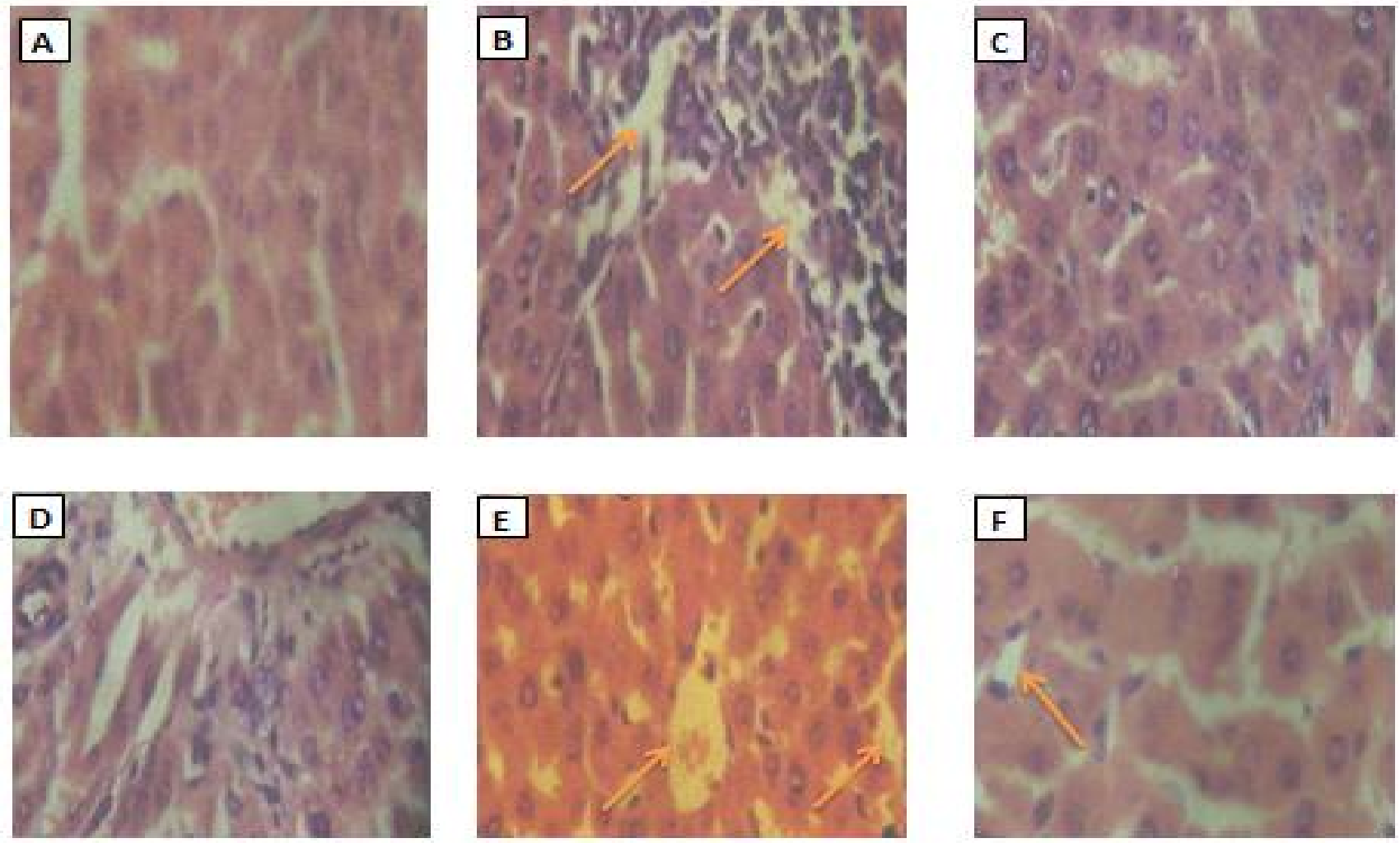

Fig. 5. Histological analysis of liver sections on the effect of $C$. mannii after expose to radiation.

${ }^{*}$ Hepatocytes showing abnormal morphology are represented by the yellow arrow. A: Group I (control), B: Group II (IR only), C: Group III (2.4 $\mathrm{mg} / \mathrm{kg} b$. wt.), D: Group IV (4.8 $\mathrm{mg} / \mathrm{kg} b . w t$.), E: Group V (IR + $2.4 \mathrm{mg} / \mathrm{kg} b$. wt.) and F: Group VI (IR + $4.8 \mathrm{mg} / \mathrm{kg} b$. wt.)

biological molecules within the cells and induce oxidative stress by the production of reacting oxygen species (ROS)/reacting nitrogen specie (RNS) in the form of free radicals as previously stated (1). These Free radicals production has been implicated in the incidence, occurrence and distribution of most metabolic abnormalities and ultimately death of cells (27).

The changes in the body weights observed among the groups exposed to radiation show the potential of bodyweight reduction by exposure to gamma radiation (Table 1). Several studies have 
shown that oxidative stress can reduce total proteins especially when it interferes with the production of albumin which constitutes more than $60 \%$ of the total proteins $(1,28-30)$. The extracts of $T$. occidentalis and $C$. mannii show their potency in the prevention of weight loss and reduced total proteins due to gamma irradiation (Table 2).

Radiations have been shown to increase lipid peroxidation as a consequence of the overwhelming production of free radicals that subdue the cell antioxidant cascade $(31,32)$. The extent of this cell membrane compromise is estimated by the measurement of the MDA and GSH levels. Therefore, an increased MDA and reduced GSH values associated with this study are expected when animals are exposed to the 6 Gy gamma radiation (Table 3, 4).

Within tolerable limits of production of free radicals, the cell can be protected from their deleterious effects by the engagement of its endogenous antioxidant defense mechanisms which include the enzymatic and non-enzymatic systems. The enzymatic mechanisms involve the upregulation of the synthesis of antioxidant enzymes such as SOD, CAT, GPX and GST. Superoxide dismutase provides the first-line defense against ROS mediated cellular damages is provided by Superoxide dismutase which converts the superoxide radicals into hydrogen peroxide $\left(\mathrm{H}_{2} \mathrm{O}_{2}\right)$ and the hydrogen peroxide produced is catabolized by catalase into water $\left(\mathrm{H}_{2} \mathrm{O}\right)$ and oxygen $\left(\mathrm{O}_{2}\right)$. Thus, ROS generated from oxidative stress is neutralized $(33,34)$.

Excessive ROS as such associated with radiation will initially increase the activities of SOD and CAT and will be decreased in the long run. This may be a reason for the increased SOD and decreased CAT values observed in our studies when group II was exposed to radiation (Table 3 ). These findings are supported by several reports $(16,35,36)$.

Hydrogen peroxide can also be neutralized by the action of glutathione peroxidase (GPx). GPx uses the reduced glutathione (GSH) to reduce the $\mathrm{H}_{2} \mathrm{O}_{2}$ into $\mathrm{H}_{2} \mathrm{O}$ and $\mathrm{O}_{2}$ while GST plays an important role in the conjugation of xenobiotics with GSH in the glutathione redox cycle (37). Our findings showed that radiation significantly reduced GSH and GST while GPx is increased (Table 4) and this is collaborated by the documented findings $(28,38$, 39). The increase in GPx may be as a result of the increased hydrogen peroxide which has been shown to upregulate the gene for the synthesis of glutathione peroxidase while low levels of GSH negatively affect the synthesis of GST $(40,41)$. The extracts of $T$. occidentalis and $C$. mannii significantly reduced MDA, SOD and GPx while GSH levels, CAT and GST activities were increased (Table 3,4) as supported by documented findings (8, 40-42).

Liver function biomarkers play crucial roles in the assessment of toxicological implications of therapeutics and several extracts to the survival of humans as the liver is the site of detoxification Hepatocellular damages has been correlated with increased levels of the major biomarkers of the hepatocytes which are AST, ALT and ALP (43). Exposure of rats to gamma irradiation induces hepatic damage and a significant increase in activities of serum alanine aminotransferases (ALT), aspartate aminotransferases (AST) and alkaline phosphatase (ALP) which is consistent with the previous observations $(44,45)$. Extracts of $T$. occidentalis and $C$. mannii, reduced AST, ALT and ALP at a dosage-dependent manner with a dosage of 4.8 $\mathrm{mg} / \mathrm{kg}$ being effective in the reduction of the radiation effect on liver enzymes. These findings are in line with the reports of 35 and 38. Radiation caused severe portal congestion and vacuolar degeneration while the control has no visible lesion. Extracts of $T$. occidentalis and $C$. mannii showed slight or moderate vacuolar degeneration to signify the ameliorating effect of extracts against radiation (Fig. $4,5)$. These histological sections give further credence to the increased values of liver enzymes when animals are exposed to irradiation.

The ability of the extracts of $T$. occidentalis and C. mannii to reduce lipid peroxidation and improve antioxidant capacities suggests that these extracts, possibly contain some bioactive agents capable of scavenging free radicals and preventing radiationinduced lipid peroxidation. Thus, they could inhibit the disruption of membrane integrity by reactive oxygen species during radiation exposure. The seed of $T$. occidentalis is very rich in oil, especially unsaturated fatty acids which form $61 \%$ of the oil. It was reported that fluted pumpkin seeds contain fat, protein and carbohydrate (46). The seed also contains a high level of vitamin A which possesses antioxidant capacity $(14,47)$. Similarly, seeds of $C$. mannii have been shown to possess a significant quantity of vitamins $A$ and $E$ which is also essential in antioxidant cascade (10).

\section{Conclusion}

From the findings of this study in which there are evidence of reduction in the tissue and serum biochemical markers as well as reduced histological indices of toxicity, which could be due to the suppression of reactive oxygen species generation and induction of the synthesis of the antioxidant enzymes, this study concludes that extracts of $T$. occidentalis and $C$. mannii at $4.8 \mathrm{mg} / \mathrm{kg} \mathrm{b}$. wt. are effective herbal remedies in the prevention and amelioration of the consequences of oxidative stress due to exposure to ionizing radiation.

\section{Acknowledgements}

The authors are grateful to the members of staff of the Departments of Biochemistry, Botany and Veterinary Anatomy, University of Ibadan, Ibadan, Oyo State, Nigeria for their support in various ways especially the availability of their laboratories and herbarium for the conduct of this research.

\section{Authors' contributions}

The study was conceived and supervised by NSO. All authors participated in its design, the procurement and administration of extracts to experimental animals were by UOM. The laboratory analysis was 
carried out by UOM and IEJ under the supervision of NSO. All authors were involved in the preparation, reading and approval of the manuscript.

\section{Conflict of interests}

Authors do not have any conflict of interest to declare.

\section{Ethical approval}

Ethical approval and consent to undertake this study was approved by the Animal Care and Use Committee of the Faculty of Basic Medical Sciences, College of Medicine, University of Ibadan, Nigeria.

\section{References}

1. Nwozo SO, Yakubu OF, Oyinloye BE. Protective effect of aqueous extracts of Aframomum meleguetaon $\gamma$-radiationinduced liver damage in male wistar rats. Mil Med Sci Lett (Voj Zdrav Listy). 2013;82(3):126-32. https://doi.org/10.31482/mmsl.2013.018

2. El Kader MAA, Abulyazid I, Mohga SA, Hayat MS, Kamel WM. Evaluation of salicin isolated from Salix subserrata as a radioprotector against gamma irradiation induced ultrastructural and electrophoretic changes in spleen tissue in rats. UK J Pharm Biosci. 2015;3(2):46-59. http://dx.doi.org/10.20510/ukjpb/3/i2/89346

3. Lett JT. Damage to cellular DNA from particulate radiation, the efficacy of its processing and the radio-sensitivity of mammalian cells: Emphasis on DNA strand breaks and chromatin break. Radiat Environ Biophys. 1992;31:257-77. https://doi.org/10.1007/bf01210207

4. Daniniak N, Tann BJ. Utility of biological membranes as indicators for radiation exposure: alterations in membrane structure and function over time. Stem Cells. 1995;13:142-52. https://www.ncbi.nlm.nih.gov/pubmed/7488940

5. Maisin JR. Chemical radioprotection: past present and future prospects. Int J Radiat Biol. 1998;73:443-50. https://doi.org/10.1080/095530098142284

6. Coleman CN, Blackley WF, Fike JR, Mcvltie TJ, Meeting NF, Mitchell JB et al. Molecular and cellular biology of moderatedose (1-10Gy) radiation and potential mechanisms of radiation protection: Report of a workshop at bethesda, Maryland, December, 17-18, 2001). Radiat Res. 2003;159:812-34. https://doi.org/10.1667/rr3021

7. Fabricant DS, Farnsworth NR. The value of plants used in traditional medicine for drug discovery. Environ Health Perspect.

https://doi.org/10.1289/ehp.01109s169

8. Airaodion AI, Ogbuagu EO, Ekenjoku JA, Ogbuagu U, Airaodion EO. Therapeutic effect of methanolic extract of Telfairia occidentalis leaves against acute ethanol-induced oxidative stress in wistar rats. Int J BioSci BioTechnol. 2019; 11(7):179-89. https://journals.eduindex.org/index.php/ijbsbt/article/view/6240

9. Achu MB, Fokou E, Tchiégang C, Fotso M, Tchouanguep FM. Nutritive values of some Cucurbitaceae oil seeds from different regions in Cameron. Afr J Biotechnol. 2005;4(10):1329-34. http://www.academicjournals.org/AJB

10. Besong SA, Ezekwe MO, Fosung CN, Senwo ZN. Evaluation of nutrient composition of African melon oilseed (Cucumeropsis mannii Naudin) for human nutrition. Int J Nutr Metab. 2011;3(8):103 -08. http://www.academicjournals.org/ijnam

11. Samaila RS, Chukwu O. Development of a motorized 'egusi' melon seeds oil expeller. J Agricult Engineer Technol. 2014;22(2):13-25.

http://www.jaet.com.ng/index.php/Jaet/article/view/82/70
12. Onu PN. Effect of aqueous extract of Telfairia occidentalis leaf on the performance and haematological indices of starter $\begin{array}{lll}\text { broilers. Vet } & \text { Sci. }\end{array}$ https://doi.org/10.5402/2012/726515

13. Eze BC, Ezejindu DN, Ogbodo EC, Ezeugwunne IP, Amah AK, Agada UN et al. The effects of aqueous leaf extract of Telfairia occidentalis (fluted pumpkin) on some hematological parameters in adult female wistar rats. J Prev Med Holist Health. https://doi.org/10.18231/j.jpmhh.2019.020

14. Kuku A, Etti UJ, Ibironke IS. Processing of fluted pumpkin seeds, Telfairia occidentalis (Hook. f.) as it affects growth performance and nutrient metabolism in rats. Afr J Food Agric Nutr Dev. 2014;14(5):1992-2014. https://www.researchgate.net/ publication/285153151

15. Teugwa CM, Thaddée B, Bruno TT, Pascaline CM, Denis Z. Antihyperglycaemic globulins from selected Cucurbitaceae seeds used as antidiabetic medicinal plants in Africa. BMC Complement Altern Med. 2013;13:63-70. https://doi.org/10.1186/1472-6882-13-63

16. Oore-Oluwapo OD, Wahab AO, Gideon O. Effects of methanol extract of Telfairia occidentalis seed on serum lipid profile, biochemical and antioxidant activity in female wistar rats. Euro J Med Plants. 2016;15(2):1-8. https://doi.org/10.9734/EJMP/ $2016 / 26723$

17. Tajudeen OJ, Adedayo OA, Ganiyu O, Aline AB. Phenolic extracts and amino acids content from Cucumeropsis manni Naudin and Citrullus lanatus inhibit relevant enzymes of erectile dysfunction in rat's penile tissue. Biochem Biophys Rep. 2017;12:5-11. https://doi.org/10.1016/j.bbrep.2017.08.001

18. Krzyczkowska J, Kozłowska M. Effect of oils extracted from plant seeds on the growth and lipolytic activity of Yarrowia lipolytica yeast. J Am Oil Chem Soc. 2017;94:661-71. https://doi.org/10.1007/s11746-017-2975-1

19. Gornall AC, Bardawill EJ, David MM. Determination of serum proteins by means of Biuret reaction. J Biol Chem. 1949;177:364-65. http://citeseerx.ist.psu.edu/viewdoc/download? doi=10.1.1.420.9605\&rep=rep1\&type=pdf

20. Varshney R, Kale RK. Effects of calmodulin antagonists on radiation- induced lipid peroxidation in microsomes. Int Radiat Biol. 1990;58:733-43. https://doi.org/10.1080/09553009014552121

21. Sinha AK. Colorimetric assay of catalase. Anal Biochem. 1972; 47:389-94. https://doi.org/10.1016/0003-2697(72)90132-7

22. Misra HP, Fridovich I. The generation of superoxide radical auto-oxidation of hemoglobin. J Biol Chem. 1972;247:6960-62. https://www.jbc.org/content/247/21/6960.long

23. Hafeman DG, Sunde RA, Hoekste WG. Effect of dietary selenium on erythrocyte and liver glutathione peroxidase in the rat. J Nutr. 1974;104:580-87. https://doi.org/10.1093/jn/104.5.580

24. Askelöf P, Guthenberg C, Jakobson I, Mannervik B. Purification and characterization of two glutathione $S$-aryltransferase activities from rat liver. Biochem J. 1975; 147:513-22. https://doi.org/10.1042/bj1470513

25. Beutler E, Duron O, Kelly BM. Improved method of determination of blood glutathione. J Lab Clin Med. 1963;61 882-88. http://www.garfield.library.upenn.edu/classics1986/ A1986A563500001.pdf

26. Reitman S, Frankel S. A colorimetric method for the determination of serum glutamic oxaloacetic and glutamic pyruvic transaminase. Am J Clin Pathol. 1957;28:56-63. https:// doi.org/10.1093/ajcp/28.1.56

27. Sankaranarayanan K. Estimation of the genetic risks of exposure to ionizing radiation in human: current status and emerging perspectives. J Radiat Res. 2006;47:57-66. https://doi.org/10.1269/jrr.47.b57

28. Dadheech G, Praveen S, Shiv G. Oxidative stress-induced response of some endogenous antioxidants in Schizophrenia $\begin{array}{lll}\text { Ind J Clin Biochem. 2012;27(3):278-83 } & \end{array}$ https://doi.org/10.1007/s12291-012-0193-z

29. Tetik S, Kiliç A, Aksoy H, Rizaner N, Ahmad S, Yardimci T. Oxidative stress causes plasma protein modification. Indian $\mathrm{J}$ 
$\operatorname{Exp}$

Biol.

https://www.researchgate.net/publication/272187515

30. Lima CV, Tarcisio P, Ribeiro C. Radiation-induced changes in the electrophoretic profile of serum albumin. Braz Arch Biol Technol. 2016;59: e17160246. https://doi.org/10.1590/1678-43242016160246

31. Mishra KP. Cell membrane oxidative damage induced by $\gamma$ radiation and apoptotic sensitivity. J Environ Pathol Toxicol Oncol.

2004;23:1-72. https://doi.org/10.1615/jenvpathtoxoncol.v23.i1.60

32. Deepti D, Amit KD, Harsha L, Bhalla PJS, Deepak B. Protective effect of Terminalia chebula in modulating oxidative damages against gamma irradation induced lethality in rats. Int J Res Pharm Biomed Sci. 2012; 3(5):734-42.

33. Tiwari BK, Kanti BP, Abidi AB, Syed IR. Markers of oxidative stress during diabetes mellitus. J Biomarkers. 2013; Article ID 378790:1-8. https://doi.org/10.1155/2013/378790

34. Asmat U, Abad K, Ismail K. Diabetes mellitus and oxidative stress-A concise review. Saudi Pharm J. 2016;24:547-53. http://dx.doi.org/10.1016/j.jsps.2015.03.013

35. Eseyin OA, Udoh I, Ekpo A, Edoho EJ, Igboasoiyi AC. Biochemical effects of the seed extract of Telfairia occidentalis in rats. Int J Pharmacol. 2007;3:198-200. http://docsdrive.com/pdfs/ansinet/ijp/2007/198-200.pdf

36. Erejuwa 00. Oxidative stress in diabetes mellitus: Is there a role for hypoglycemic drugs and/or antioxidants. In: Lushchak V, editor. Oxidative Stress and Diseases. London: InTech Open; 2012. p. 217-46.

37. Jabir FA, Al Ali AS. Biochemical study and gene expression of Glutathione-S-Transferase (GST) in induced asthma in rat Orient J Chem. 2015; 31(3): 1587-94. http://dx.doi.org/10.13005/ ojc/310337

38. Ogbuagu EO, Airaodion AI, Ogbuagu U, Airaodion EO. Prophylactic propensity of methanolic extract of Vernonia amygdalina leaves against acute ethanol-induced oxidative stress in wistar rats. Int J Biosci Biotechnol. 2019;11(7):37-46. https://www.researchgate.net/publication/334646848
39. Xie LH, Zhang XH, Hu XD, Min XY, Zhou QF, Zhang HQ. Mechanisms of an increased level of serum iron in gammairradiated mice. Radiat Environ Biophys. 2016;55:81-88. https://doi.org/10.1007/s00411-015-0623-4

40. JosÉ MM, Cristina P, Ignacio NC. Antioxidant enzymes and human diseases. Clin Biochem.1999;32(8):595-603. https://doi.org/10.1016/s0009-9120(99)00075-2

41. Cássia RP, Beny S. The effect of sixteen medicinal plants used in the Brazilian pharmacopoeia on the expression and activity of glutathione S-transferase in hepatocytes and leukemia cells. Pharm Biol.

https://doi.org/10.3109/13880200903029340

42. Ajani RS, Akinyemi AR. Telfairia occidentalis leaf and seed extract as possible preventive and therapeutic agents for induced benign prostatic hyperplasia. Eur J Med Plants. 2016; 12(1):1-11. https://doi.org/10.9734/EJMP/2016/22856

43. Owoade AO, Adetutu A, Airaodion AI, Ogundipe OO Toxicological assessment of the methanolic leaf extract of Bridelia ferrugenia. The J Phytopharmacol. 2018;7(5):419-24. http://www.phytopharmajournal.com/Vol7_Issue5_03.pdf

44. Mansour HH. Protective role of carnitine ester against radiation-induced oxidative stress in rats. Pharmacol Res. 2006; 54: 165-71. http://dx.doi.org/10.1016/j.phrs.2006.04.003

45. Salem AM, Mohammaden TF, Ali MA, Mohamed EA, Hassan HF. Ellagic and ferulic acids alleviate gamma radiation and aluminium chloride-induced oxidative damage. Life Sci. 2016; 160:2-11. http://dx.doi.org/10.1016/j.lfs.2016.07.006

46. Longe OG, Farinu GO, Fetuga BL. Nutritious value of fluted pumpkin (Telfairia occidentalis). J Agric Food Chem. 1983, 31(5): 989-92. http://dx.doi.org/10.1021/jf00119a017

47. Okoye EI, Orakwue FC The chemical evaluation and anti-microbial screening of extracts from seeds and leaves of Telfaria occidentalis (Fluted Pumpkin). Chem Res J. 2019;4(3):98-104. https://www.researchgate.net/publication/336375204 